\title{
Distribution of Lepidopteran Larvae on Norway Spruce: Effects of Slope and Crown Aspect
}

\author{
Ján Kulfan, ${ }^{1,3}$ Katarína Dvořáčková, ${ }^{2}$ Peter Zach, ${ }^{1}$ Michal Parák, ${ }^{1}$ and Marek Svitok ${ }^{4,5}$ \\ ${ }^{1}$ Institute of Forest Ecology, Slovak Academy of Sciences, Štúrova 2, 96053 Zvolen, Slovak Republic (kulfan@savzv.sk; \\ zach@savzv.sk; parak@savzv.sk), ${ }^{2}$ State Nature Conservancy SR, Administration CHKO Polana, J. M. Hurbana 20, 96001 \\ Zvolen, Slovak Republic (katarinka83@gmail.com), ${ }^{3}$ Corresponding author, e-mail: kulfan@savzv.sk, ${ }^{4}$ Department of \\ Biology and General Ecology, Faculty of Ecology and Environmental Sciences, Technical University in Zvolen, Masaryka \\ 24, 96001 Zvolen, Slovak Republic (svitok@tuzvo.sk), and ${ }^{5}$ Eawag Swiss Federal Institute of Aquatic Science and Technology, \\ Department of Aquatic Ecology, Centre of Ecology, Evolution and Biogeochemistry, Seestrasse 79, CH-6047 Kastanienbaum, \\ Switzerland
}

Received 23 June 2015; Accepted 10 December 2015

\begin{abstract}
Lepidoptera associated with Norway spruce, Picea abies (L.) Karsten, play important roles in ecosystem processes, acting as plant pests, prey for predators, and hosts for parasites and parasitoids. Their distribution patterns in spruce crowns and forests are only poorly understood. We examined how slope and crown aspect affect the occurrence and abundance of moth larvae on solitary spruce trees in a montane region in Central Europe. Moth larvae were collected from southern and northern crowns of trees growing on south- and north-facing slopes (four treatments) using emergence boxes at the end of winter and by the beating method during the growing season. Species responses to slope and crown aspect were not uniform. Treatment effects on moth larvae were stronger in the winter than during the growing season. In winter, the abundance of bud-boring larvae was significantly higher in northern than in southern crowns regardless of the slope aspect, while both slope and aspect had marginally significant effects on abundance of miners. During the growing season, the occurrence of free-living larvae was similar among treatments. Emergence boxes and beating spruce branches are complementary techniques providing valuable insights into the assemblage structure of moth larvae on Norway spruce. Due to the uneven distribution of larvae detected in this study, we recommend adoption of a protocol that explicitly includes sampling of trees from contrasting slopes and branches from contrasting crown aspect in all seasons.
\end{abstract}

Key words: forest herbivore, microhabitat, sampling, emergence box, beating method

Several Lepidoptera species are considered pests of Norway spruce Picea abies (L.) Karsten (e.g., Schwenke 1978, Bolov and Sinev 1990, Kulfan and Patočka 1997, Watt et al. 1997, Heiermann and Schütz 2008, Klepikov 2011, Kosibowicz et al. 2014). They damage needles, buds, cones, and other parts of host plants. Spruce moths contribute to various ecosystem processes also during nonoutbreak period. For example, adults and especially caterpillars are important prey of predators such as birds (Crawford and Jennings 1989, Venier and Holmes 2010), even in winter (Pettersson et al. 1995). They also serve as hosts for parasites and parasitoids (Schwenke 1978), etc.

Spruce forests within Europe host rich assemblages of Lepidoptera (Karisch 1995, Aarvik and Bakke 1999, Liška et al. 2008). However, there are only few studies focusing on the assemblages of Lepidoptera larvae dwelling on Norway spruce (Kulfan 1994, 1998; Kulfan and Patočka 1997; Kulfan et al. 2010).

Previous studies have revealed considerable differences in occurrence and abundance of moth larvae and other phytophagous insects, or in leaf damage caused by them, between northern and southern slopes, between shady and sunny habitats, or between less and more illuminated parts of host plants (Maiorana 1981; Moore et al. 1988; Basset 1991; Potter 1992; Richardson et al. 1997; Weber 1997; Mazza et al. 1999; Auslander et al. 2003; Battisti et al. 2005; Stoeckli et al. 2008; Holecová and Kulfan 2011; Kulfan et al. 2011, 2013). The experimental rearing of five species within the family Geometridae on spruce twigs in the laboratory shows that larvae of three species have no roosting preferences for either terminal-illuminated or basal—shaded parts of twigs, one species prefers terminal and one species basal parts of twigs (Dvořáčková et al. 2010). Moth larvae migrate from spruce branches placed in emergence boxes (photoeclectors), displaying a positive phototactic response (Kulfan and Šušlík 1995, Kulfan et al. 2010). These findings suggest that insect herbivores respond to variation in local microhabitat conditions. Studies of insects dwelling in oak crowns show that within-tree variation in the presence and abundance of some insect taxa should be taken into consideration in sampling designs (Stork et al. 2001, Roslin et al. 2006). 
Despite a wide native distribution of Norway spruce and its ecological and taxonomic differentiation (Latałowa and Van der Knaap 2006), this tree species prefers cool and humid regions with short growing period and long winter. Warmer microhabitats in cool environments provide more appropriate conditions for development and survival of various insect species than microhabitats with cool climate (cf. e.g., Zumr 1984, Schweizerischer Bund für Naturschutz 1987, Weiss et al. 1988, Zach et al. 1995, Ashton et al. 2009). Hence, we expect, in general, more insects dwelling in spruce trees in warmer habitats (e.g., on south-facing slopes) and warmer microhabitats (e.g., in southern crowns). The horizontal within-tree distribution of moth larvae living on spruce and their response to slope and crown aspect have not yet been examined.

This study aims to reveal possible differences in occurrence and abundance of moth larvae developing on branches of solitary Norway spruce trees in fragmented spruce forests at the end of winter and during the growing season. In particular, we were interested in how occurrence and abundance of moth larvae differ between northern and southern crowns of spruce trees growing on northversus south-facing slopes. To get acquainted with this in more detail, we used two sampling techniques: 1) emergence boxes at the end of winter and 2) beating branches during the growing season.

The obtained distribution data about moth larvae in spruce crowns are important to design sampling protocols for assessing pest species in forestry practices during nonoutbreak period, to record prey of predators and monitor insect diversity.

\section{Materials and Methods}

\section{Study Area}

The study was carried out in the Western Carpathians, the Veporské vrchy mountain range, Slovakia, Central Europe $\left(48^{\circ} 34^{\prime} 44^{\prime \prime} \mathrm{N}, 19^{\circ}\right.$ $36^{\prime} 37^{\prime \prime} \mathrm{E}$, altitude $800-890 \mathrm{~m}$ asl). The area is characterized by a mountain climate with slight temperature inversion, mean air temperature ranging from -5 to $-6.5^{\circ} \mathrm{C}$ in January and from 13.5 to $16^{\circ} \mathrm{C}$ in July, and annual rainfall of $800-1,100 \mathrm{~mm}$ (Michalko et al. 1986). The weather conditions during the study in 2007 were ordinary, showing no significant departures from mean values in the long term. The study area is a hilly pasture land with solitary Norway spruce trees and groups of spruce trees patchily distributed in the fragmented forest landscape.

\section{Sampling Moth Larvae}

Moth larvae were sampled from solitary 30-yr-old spruce trees growing on northern and southern slopes with approximate inclination of $25^{\circ}$. As seasonality (e.g., changing temperatures) may influence distribution patterns of insects within and between slopes and within and between trees on these slopes (Mani 1968, Connor and Taverner 1997, Pincebourde et al. 2007, Bennie et al. 2008), moth larvae occurring on spruce branches were sampled at the end of winter (cool period) and during the growing season (warm period). Larvae were sampled within a large area of $\sim 10 \mathrm{~km}^{2}$.

At the end of winter, in March 2007, a total of 10 solitary spruce trees were selected at random on northern slopes, followed by a total of 10 randomly selected trees on southern slopes. From each tree, paired branch samples were collected, one from the northern crown and one from the opposite southern crown. Each sample consisted of a total of 20 terminal parts of branches $(50 \mathrm{~cm}$ long each) cut from the same tree at heights of 1-3 $\mathrm{m}$ above the ground. The samples were placed separately in emergence boxes (photoeclectors) in the laboratory kept under ambient conditions. Moth larvae and hatched adults of moths emerged from boxes were collected and identified in the laboratory.

During the growing season, from May to September 2007, moth larvae were sampled monthly by beating from Norway spruce branches at heights of 1-3 $\mathrm{m}$ above the ground, using a beating tray with a diameter of $1 \mathrm{~m}$. The trees from which branch samples were taken at the end of winter were not beaten. Each month, we collected a total of 10 samples of larvae from northern branches of randomly selected solitary trees, and a total of 10 samples were taken from southern branches of trees growing on north-facing slopes. The same sampling technique and sampling arrangement were applied to south-facing slopes. One sample consisted of larvae that had dropped into the beating tray from a total of 20 branches which were $1 \mathrm{~m}$ long each; it was obtained from three trees (five to eight branches from one tree). Samples from northern branches were taken from different trees then those from southern branches. Larvae were collected from the same trees each month.

The larvae were preserved in $70 \%$ ethanol and identified according to Patočka et al. (1960). Small larvae within the genera Macaria (Geometridae) and Eupithecia (Geometridae) were taken alive, reared in the laboratory, and identified to species in older instars, as pupae or adults. Several individuals have not been identified to the species level. For practical reasons, larvae within the genus Macaria were treated as a single taxon (Macaria signaria Hübner + Macaria liturata Clerck). The larvae within the subfamily Naryciinae (Psychidae) and those within the genus Argyresthia (Argyresthiidae) were also considered to represent a single taxon. The nomenclature of Lepidoptera follows Pastorális et al. (2013).

\section{Data Analysis}

For each of the four treatment combinations (i.e., slope $\times$ crown), the faunal data (total number of larvae) from the five sampling intervals during the growing season were pooled $(N=10$ pooled replicates per treatment combination).

Numbers of moth larvae were modeled as a function of slope aspect (northern or southern) and crown aspect (northern or southern). As the variances of larval counts far exceeded the mean values (i.e., data were overdispersed), we specified a negative-binomial error distribution in the statistical models (O'Hara and Kotze 2010). Data from the late winter and growing season were analyzed separately due to the different sampling designs used. Numbers of larvae collected at the end of winter were fitted using generalized linear mixed-effect models (GLMM, Bolker et al. 2009) via automatic differentiation (Fournier et al. 2012). Crown and slope aspect were considered fixed effects in GLMMs, while the repeatedly sampled trees were considered as random effects. Generalized linear models (GLM, McCullagh and Nelder 1989) were fitted to the data from the growing season. Separate models were fitted to the total number of larvae collected at the end of winter and during the growing season, and to the most abundant taxa or ecological groups (guilds) of larvae, including the number of Batrachedra pinicolella Zeller (Batrachedridae), all mining larvae, all bud-boring larvae at the end of winter, the number of B. pinicolella, Peribatodes secundaria Denis \& Schiffermüller (Geometridae), Eupithecia tantillaria Boisduval (Geometridae), and all free-living larvae recorded during the growing season.

Mean values along with $95 \%$ confidence intervals were plotted for comparative purposes. Confidence limits were computed by nonparametric bootstrap $(10,000)$ using a bias-corrected accelerated percentile method (Efron and Tibshirani 1986). Confidence intervals for winter samples were adjusted for repeated measurements of the same trees (Loftus and Masson 1994). 
Rarefaction accumulation curves (Hurlbert 1971) were used to find expected species richness by sampling moth larvae in the late winter and during the growing season. $\mathrm{X}$-axes of sample-based accumulation curves were rescaled to number of individuals. Species richness of particular treatments were also extrapolated by biascorrected abundance-based Chao estimator (Chao1) and biascorrected incidence-based Chao estimator (Chao2), both for estimating lower bounds of undetected number of species, which is precisely explained in Chiu et al. (2014).

Principal coordinates analysis (PCoA, Gower 1966) was used to analyze species abundance data of both the late winter and the growing season larvae assemblages. The data were square-root transformed to down weight the most abundant species. Distances between replicates were calculated with Bray-Curtis dissimilarity index (Bray and Curtis 1957). As mixed modeling for dissimilaritybased multivariate methods is underdeveloped, we adopted an indirect approach and used the first axes of PCoAs as proxies of moth larvae assemblage structure. The extracted axes were modeled as a function of slope and crown aspect. Linear mixed-effect model (LMM, Lindstrom and Bates 1988) was fitted on the axis of the late winter assemblage. We specified a constant variance structure (Davidian and Giltinan 1995) in LMM and allowed different variances for slope aspect levels, as ratio of the variances was not equal to $1\left(F_{(19,19)}=3.79, P=0.006\right)$. Linear model was fitted on the axis of the growing season assemblage. Results of PCoAs were plotted in two-dimensional ordinations.

Statistical analyses were performed in R (R Core Team 2015) using the packages boot (Canty and Ripley 2015), glmmADMB (Skaug et al. 2015), MASS (Venables and Ripley 2002), nlme (Pinheiro et al. 2015), and vegan (Oksanen et al. 2015).

\section{Results}

\section{Moth Larvae at the End of Winter}

At the end of winter, we collected a total of 495 individuals of moths (larvae or adults) from northern and southern crowns of spruce trees growing on north- and south-facing slopes. They belonged to 11 taxa (10 species and one species group identified to the genus level) and three ecological groups (guilds) of Lepidoptera: needle-mining larvae (young larvae or larvae of all instars within this group are miners living in webs among needles; families Gelechiidae, Batrachedridae, Tortricidae-344 individuals), bud-boring larvae (Argyresthiidae-137 individuals), and free-living larvae feeding on spruce (Geometridae-14 individuals; Table 1). These species overwinter on Norway spruce branches as larvae.

The species richness sampled in particular combinations of slope and crown aspect ranged from 8 (in southern crowns on north facing slopes) to 11 (in northern crowns on south facing slopes; Table 2). The total number of taxa on north- and south-facing slopes, and in northern and southern crowns was overall similar (10-11). Abundant species were found in all slope $\times$ crown aspect combinations (Table 1).

The total abundance of all overwintering larvae was significantly affected by the crown aspect; however, this effect was dependent on the slope aspect (Table 3). On north-facing slopes, larval abundance was significantly higher in northern than in southern crowns $\left(\chi_{(1)}^{2}=4.6, P=0.033\right)$, whereas on south-facing slopes, we found the opposite pattern $\left(\chi_{(1)}^{2}=3.1, P=0.078\right.$; Fig. 1a). Similar, marginally nonsignificant effects of crown and slope aspect were detected in mining larvae (Table 3; Fig. 1b). The dominant species B. pinicolella showed different distribution patterns depending on the slope. On north-facing slopes, the effect of crown on the abundance of this species was not significant $\left(\chi_{(1)}^{2}=0.16, P=0.687\right)$, whereas on south-facing slopes it was significant, with a much higher abundance of larvae in southern than northern crowns $\left(\chi_{(1)}^{2}=12.7, P<0.001\right.$; Fig. 1c). The larvae of another abundant species, Epinotia nanana Treitschke, were significantly affected by the slope aspect, showing higher abundance on south-facing slopes $\left(\chi_{(1)}^{2}=6.18, P=0.013\right)$; the effect of crown aspect was not significant. Regardless of the slope aspect, the abundance of bud-boring larvae was significantly higher in northern than in southern crowns (Table 3; Fig. 1d).

Rarefaction accumulation curves showed small differences between northern and southern crowns in north-facing slopes and obvious differences between northern and southern crowns in southfacing slopes (Fig. 2a). Based on the species richness estimators, we sampled $60-97 \%$ species (Chao1) and $79-96 \%$ species (Chao2) in the particular treatments. Our sampling effort appeared to be sufficient to gauge expected species richness by Chao1 and Chao 2 in most treatments. More samples would be necessary to record expected species richness only in southern crowns on south-facing slopes (Table 2).

The first two PCoA axes explained 41\% (21 and 20\%, respectively) of the variability in the late winter assemblage (based on square-root transformed species abundance data; Fig. 3a). Results of LMM showed significant effect of the crown aspect on the assemblage composition $\left(F_{(1,18)}=11.19, P=0.004\right)$. Samples from the southern crowns (empty symbols) are located mostly on the left side of the first axis and the samples from the northern crowns (solid symbols) on the right side (Fig. 3a). The effects of slope aspect and its interaction with the crown aspect were not significant $\left(F_{(1,18)}=\right.$ $0.04, P=0.841$ and $F_{(1,18)}=0.30, P=0.592$, respectively).

\section{Moth Larvae During the Growing Season}

During the growing season, a total of 917 larvae belonging to 29 taxa (28 species and 1 larva classified as a higher taxon-a subfamily) were recorded in southern and northern crowns of spruce trees on south- and north-facing slopes. Recorded species were classified within the following ecological groups (guilds): needle-mining larvae and larvae living in webs among needles (feeding externally or internally on needles; Gelechiidae, Batrachedridae, and Tortricidae; 130 individuals); free-living larvae feeding on spruce (Lasiocampidae, Sphingidae, Geometridae, Erebidae—subfamily Lymantriinae and Noctuidae; 747 individuals); and larvae feeding on lichens and algae (Psychidae and Erebidae-subfamily Arctiinae; 40 individuals; Table 4).

In all habitats, the richness of taxa recorded was similar, ranging from 19 on north-facing slopes and southern crowns to 21 in other situations (Table 2). In total, 27 taxa were documented in northern and a total of 22 taxa in southern crowns. Differences in species richness were primarily attributed to the presence or absence of less abundant species (Table 4). North- and south-facing slopes differed in the number of taxa only slightly (26 taxa recorded on northfacing and 24 taxa on south-facing slopes). As at the end of winter, abundant species were recorded in all situations.

No significant effect of crown or slope aspect on the abundance of all larvae, all free-living larvae, and on the two most abundant species, P. secundaria and E. tantillaria, was detected (Table 3). One species only, B. pinicolella, was significantly more abundant on south-facing than on north-facing slopes (Fig. 4a). The abundance of free-living larvae was lower in southern crowns of trees on southfacing slopes, although this was not significant (Fig. 4b). 
Table 1. Relative abundance (\%) of Lepidoptera larvae on Norway spruce trees on north- (N) and south-facing slopes (S) and in north- (N) or south-facing crowns (S) at the end of winter; B-bud-boring larvae; M-needle-mining larvae; F-free-living larvae

\begin{tabular}{|c|c|c|c|c|c|}
\hline \multirow[t]{2}{*}{ Family, Species } & \multirow[t]{2}{*}{ Guild } & \multicolumn{4}{|c|}{ Aspect: slope/crown } \\
\hline & & $\mathrm{NN}$ & NS & $\mathrm{SN}$ & SS \\
\hline \multicolumn{6}{|l|}{ Argyresthiidae } \\
\hline Argyresthia spp. & B & 44.3 & 24.6 & 31.0 & 18.4 \\
\hline \multicolumn{6}{|l|}{ Gelechiidae } \\
\hline Chionodes electella Zeller & M & 12.4 & 8.7 & 6.0 & 5.5 \\
\hline \multicolumn{6}{|l|}{ Batrachedridae } \\
\hline Batrachedra pinicolella Zeller & M & 21.7 & 34.7 & 18.2 & 46.8 \\
\hline \multicolumn{6}{|l|}{ Tortricidae } \\
\hline Archips oporana L. & $\mathrm{M}$ & 1.0 & 1.5 & 2.3 & 0.5 \\
\hline Dichelia histrionana Frölich & $\mathrm{M}$ & 0.0 & 2.9 & 0.8 & 0.5 \\
\hline Pseudohermenias abietana $\mathrm{F}$. & M & 2.1 & 5.8 & 5.3 & 4.5 \\
\hline Epinotia nanana Treitschke & M & 14.4 & 20.3 & 31.1 & 22.8 \\
\hline \multicolumn{6}{|l|}{ Geometridae } \\
\hline Peribatodes secundaria Denis and Schiffermüller & $\mathrm{F}$ & 1.0 & 0.0 & 0.8 & 0.5 \\
\hline Hylaea fasciaria $\mathrm{L}$. & $\mathrm{F}$ & 2.1 & 0.0 & 1.5 & 0.5 \\
\hline Pungeleria capreolaria Denis and Schiffermüller & $\mathrm{F}$ & 0.0 & 0.0 & 1.5 & 0.0 \\
\hline Thera variata Denis and Schiffermüller & $\mathrm{F}$ & 1.0 & 1.5 & 1.5 & 0.0 \\
\hline
\end{tabular}

Table 2. Observed and estimated species richness (approximate standard error) on Norway spruce trees on north- (N) and south-facing slopes (S) and in north- (N) or south-facing crowns (S)

\begin{tabular}{|c|c|c|c|c|c|c|c|c|}
\hline \multirow[t]{3}{*}{ Species richness } & \multicolumn{4}{|c|}{ Late winter } & \multicolumn{4}{|c|}{ Growing season } \\
\hline & \multicolumn{4}{|c|}{ Aspect: slope/crown } & \multicolumn{4}{|c|}{ Aspect: slope/crown } \\
\hline & NN & NS & $\mathrm{SN}$ & SS & NN & NS & $\mathrm{SN}$ & SS \\
\hline $\mathrm{S}_{\text {obs }}$ & 9 & 8 & 11 & 9 & 21 & 19 & 21 & 21 \\
\hline $\mathrm{S}_{\text {Chao1 }}$ & $10.0(1.80)$ & $8.5(1.27)$ & $11.3(0.73)$ & $15.0(7.12)$ & $24.0(3.41)$ & $33.0(13.15)$ & $28.5(8.12)$ & $24.8(4.20)$ \\
\hline $\mathrm{S}_{\mathrm{Chao} 2}$ & $11.0(3.09)$ & $9.8(3.39)$ & $11.5(0.95)$ & $14.4(6.44)$ & $24.2(3.51)$ & $33.4(14.89)$ & $29.1(9.20)$ & $28.4(7.50)$ \\
\hline
\end{tabular}

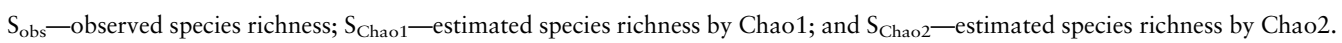

Table 3. Results of negative-binomial GLMMs (winter season) and GLMs (growing season) testing for the effect of crown, slope aspect, and their interaction on abundance of moth larvae

\begin{tabular}{llll}
\hline Variable & Slope aspect & Crown aspect & $\begin{array}{c}\text { Slope asp. } \times \\
\text { Crown asp. }\end{array}$ \\
\hline Winter season & & & \\
$\quad$ All larvae & $1.23(0.267)$ & $1.40(0.237)$ & $\mathbf{6 . 1 4}(0.013)$ \\
$\quad$ Mining larvae & $2.59(0.108)$ & $0.20(0.654)$ & $3.37(0.066)$ \\
B. pinicolella & $0.32(0.570)$ & $0.26(0.613)$ & $4.69(0.030)$ \\
$\quad$ Bud-boring larvae & $0.13(0.716)$ & $\mathbf{6 . 3 7}(0.012)$ & $2.95(0.086)$ \\
Growing season & & & \\
All larvae & $0.07(0.785)$ & $0.87(0.352)$ & $2.64(0.104)$ \\
Free-living larvae & $0.08(0.782)$ & $0.49(0.483)$ & $3.69(0.055)$ \\
B. pinicolella & $5.38(0.020)$ & $1.07(0.302)$ & $2.88(0.090)$ \\
$\quad$ P. secundaria & $0.94(0.332)$ & $0.17(0.676)$ & $1.70(0.193)$ \\
E. tantillaria & $0.02(0.892)$ & $0.11(0.736)$ & $2.78(0.096)$ \\
\hline
\end{tabular}

Likelihood-ratio $\chi^{2}$ statistics followed by probabilities (in parentheses) are displayed. Results significant at $5 \%$ level are highlighted in bold.

Rarefaction accumulation curves showed similar species richness recorded by the sampling effort used in all treatments (Fig. 2b). Based on the species richness estimators, we sampled $58-88 \%$ species (Chao1) and $57-87 \%$ species (Chao2) in the particular treatments. To record expected species richness calculated by Chao1 and Chao2 (Table 2), higher number of samples is needed than that in the study.
The first two PCoA axes explained 31\% (18 and 13\%, respectively) of the variability in the growing season assemblage (based on square-root transformed species abundance data; Fig. 3b). We did not find any significant effect of studied factors on the assemblage composition (slope: $F_{(1,36)}=0.03, P=0.860$; crown: $F_{(1,36)}=1.28$, $P=0.266$; slope $\times$ crown: $\left.F_{(1,36)}=0.03, P=0.861\right)$.

\section{Discussion}

The results of this study describe the horizontal distribution of moth larvae dwelling in Norway spruce on north- and south-facing slopes for the first time, providing a background for a proper sampling moth larvae from spruce trees. Data come from a typical central European mountain region (altitude $800-890 \mathrm{~m}$ asl) where managed spruce forests predominate. Moth larvae were collected during one year using the two most appropriate sampling methods.

Emergence boxes (cf., Cock 2013) are appropriate to record both ecto- and endophagous moth larvae overwintering on spruce branches. The main advantage of boxes is that they allow efficient obtaining of moths overwintering as larvae in buds, needles (miners), and webs. The disadvantage is that free-living larvae overwintering unprotected on needles or twigs can be mechanically injured when branches are sampled and manipulated. This might lead to underestimation of numbers of those larvae. Sample sizes are limited by the number of boxes available. The method is not suitable for collecting larvae during the growing season due to large numbers of 

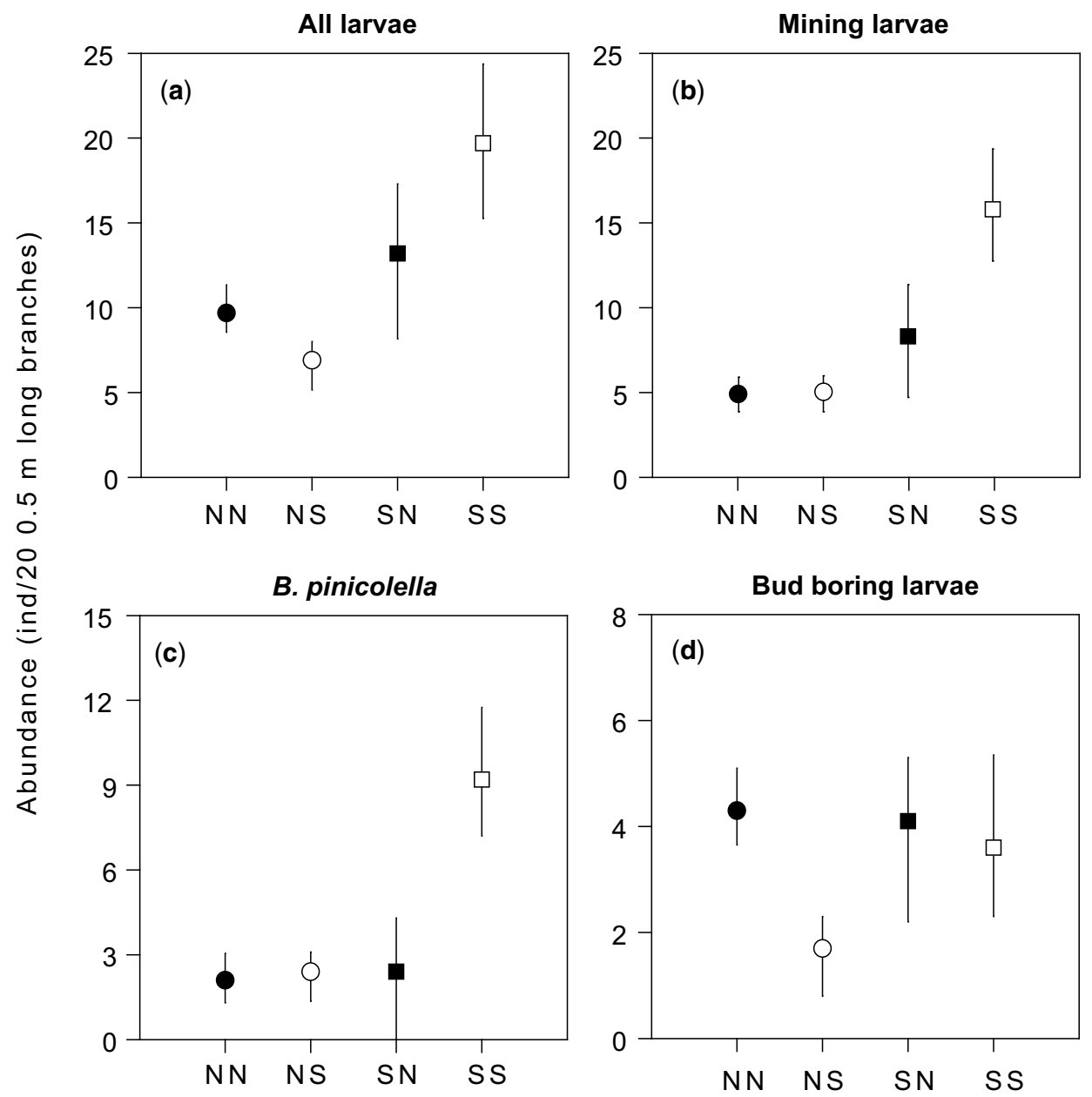

Fig. 1. (a-d) Mean abundance of moth larvae in northern (solid symbols) and southern crowns of trees (empty symbols) on north-facing (circles) and south-facing slopes (squares) at the end of winter. Habitats are denoted using four combinations of slope and crown aspects (e.g., NS-north-facing slope and southern crown). Error bars denote $95 \%$ bootstrap confidence intervals.
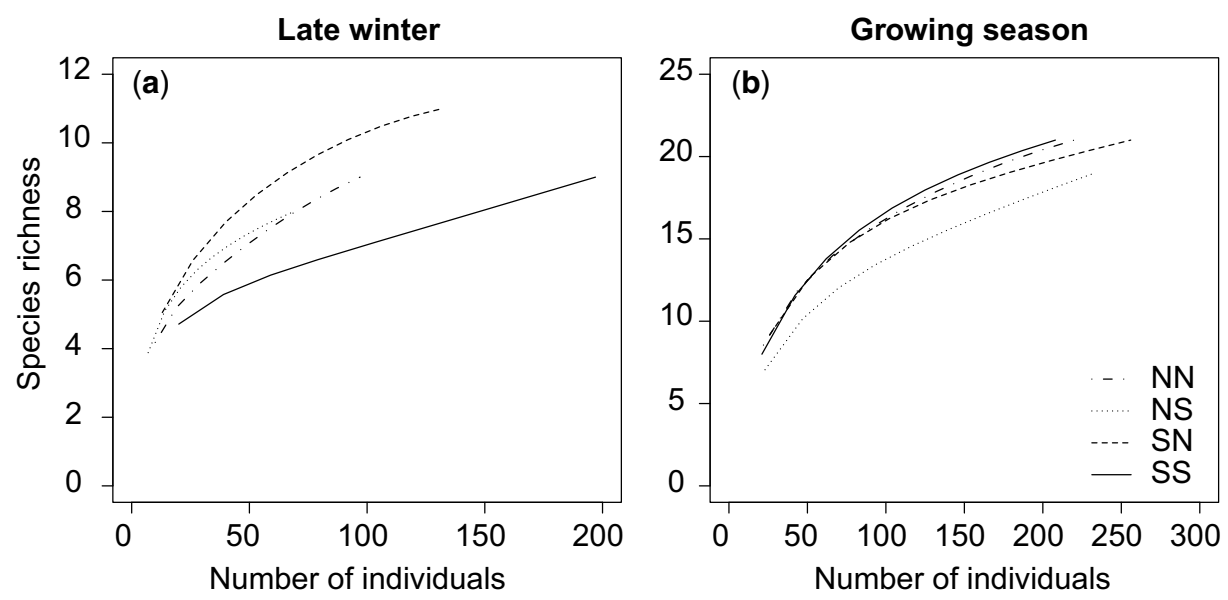

Fig. 2. Rarefaction accumulation curves for larvae assemblages on north- or south-facing slopes and in northern or southern crowns in the late winter (a) and the growing season (b). Habitats are denoted using four combinations of slope and crown aspects (e.g., NS-north-facing slope and southern crown).

predators (spiders, true bugs, wasps etc.) on spruce branches attacking larvae inside the boxes and in collecting vials.

The beating method (cf., Basset et al. 1997) allows to obtain large sample sizes of free-living larvae, providing immediate information about species occurrence on spruce branches. Endophages are not recorded, and larvae living in webs among needles are collected with less efficacy. Tiny larvae can be overlooked. The technique is time-consuming, especially when large sample sizes 

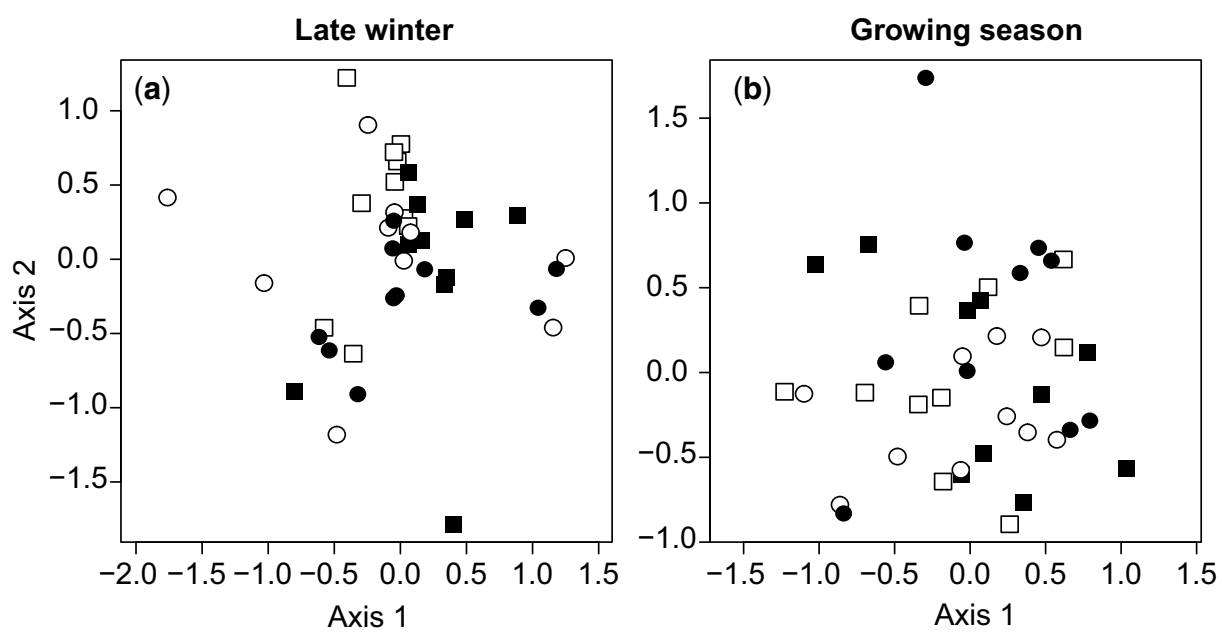

Fig. 3. Ordination graph for the first two axes of a PCoA of the late winter (a) and the growing season (b) larvae assemblages based on the Bray-Curtis distance. Solid symbols-northern crowns, empty symbols—southern crowns, circles—north-facing slopes, squares-south-facing slopes.

are needed. It is limited in use by weather conditions (rainfall, wind). The use of the method in winter can be problematical as most larvae are small, often inactive, or hidden in shelters and thus hardly detectable.

The results of the study document certain differences in occurrence and abundance of moth larvae on spruce branches between northern and southern crowns and north- and south-facing slopes. However, the general expectation and main idea of the study that moth larvae will be concentrated in warmer habitats or microhabitats (south-facing slopes and crowns) was not confirmed. The data suggest nonuniform, species-specific responses to different conditions in spruce crowns (cf., Stork et al. 2001).

Occurrence of moth larvae on north- and south-facing slopes is largely determined by females choosing their oviposition sites, as larvae have limited opportunities to migrate to trees growing elsewhere. The role of ballooning (cf., Zalucki et al. 2002, Hagstrum and Subramanyam 2010) in colonization of spruce trees by moth larvae, also, should be taken into consideration, particularly in the representatives of the subfamily Lymantriinae. However, this kind of passive spread assisted by wind is less likely in moth species recorded in this study. The oviposition strategy of females of these species is only poorly understood (Patočka et al. 1960, Schwenke 1978). In general, the choice of oviposition site depends on several factors, such as site microclimate (Moore et al. 1988, Alonso 1997, Pro Natura 1997, Connor 2006), plant age (Grossmueller and Lederhouse 1985, Navasero and Ramaswamy 1993, Pro Natura 1997, Queiroz 2002), plant architecture (Marquis et al. 2002), and host plant chemicals (Thompson and Pellmyr 1991; Dudt and Shure 1994; Grant et al. 2000, 2007). However, abiotic and biotic conditions in host trees markedly change during the long development of moth species overwintering as larvae (including species in this study). When in the adult stage, they may not be able to locate optimal oviposition sites for offspring performance (Gripenberg et al. 2007). Therefore, their larvae likely respond to changing conditions by moving to more suitable sites.

At the end of winter, differences in number of moth larvae between the four treatments were detected. On north-facing slopes, there were more caterpillars in northern crowns than in southern crowns, whereas on south-facing slopes, there were more caterpillars in southern crowns than in northern crowns (Fig. 1a). Distribution of all larvae (total abundance of larval assemblages) was determined mostly by two guilds-mining and bud-boring larvae showing different distribution pattern (Fig. $1 \mathrm{~b}$ and d).

We suppose that the larvae of mining species overwinter on spruce branches close to oviposition sites. In autumn and winter, mining larvae are tiny, usually not able to migrate horizontally within a tree to the opposite part of tree crown. However, vertical moving of larvae by lowering on silk threads is possible (Torres et al. 1997). Mining larvae live in webs among spun needles and overwinter in mined needles or silken webs (Patočka et al. 1960, Schwenke 1978). Leaf mines protect larvae from the effects of UV radiation, drought, water, wind, extreme temperatures, etc. A warmer environment in sunlit mines could be important for the larvae living in cold conditions (from autumn to spring; Connor and Taverner 1997, Pincebourde et al. 2007). The webs in which larvae live and develop are likely to provide a similar effect. Battisti et al. (2005) and Rehnberg (2006) reported elevated temperatures inside webs on sunny days compared with ambient temperatures. Thus, the mining larvae, represented by the dominant species $B$. pinicolella, recorded in high numbers in southern crowns of trees on south-facing slopes at the end of winter, may take the advantage of improved thermal conditions in their microhabitats (Fig. 1b and c). Similarly, the needle miner E. nanana was more abundant on southfacing slopes, but Hayes and Shipp (1983) reported more serious attacks caused by this species in cooler habitats-on northerly aspects and on suppressed and subdominant trees in northern England.

Unlike the mining larvae, the bud-boring ones were more common in northern than southern crowns on both north- and southfacing slopes (Fig. 1d). Features of larval development of bud-boring moths are similar to those in many mining moth species, including the use of larval shelters, long development times, and overwintering on branches (Kulfan and Patočka 1997). While the mining larvae are able to move from one site to another, leaving risky microhabitats behind them, the bud-boring larvae maintain their dwelling in the same terminal parts of shoots. These sunlight-exposed branch tips (and larvae in bud cavities) can be overheated during a long development from the late summer to the spring of the next year, especially in southern crowns (cf., Pincebourde et al. 2007). Under a cloudless sky in winter, considerable fluctuations in day-night temperatures are likely in southern crowns. It seems that northern crowns of trees are most suitable for those larvae which cannot shift their development site, thus avoiding the extreme temperature 
Table 4. Relative abundance of Lepidoptera larvae (\%) on spruce trees on north- (N) or south-facing slopes (S) and in north- (N) or southfacing crowns (S) of these trees during the growing season (May-September); M-needle-mining larvae and larvae living in webs among needles; F-free-living larvae; L-larvae feeding on lichens and algae

\begin{tabular}{|c|c|c|c|c|c|}
\hline \multirow[t]{2}{*}{ Family, (Subfamily), Species } & \multirow[t]{2}{*}{ Guild } & \multicolumn{4}{|c|}{ Aspect: slope/crown } \\
\hline & & NN & NS & $\mathrm{SN}$ & SS \\
\hline Psychidae (Naryciinae) & $\mathrm{L}$ & 1.4 & 0.4 & 2.0 & 0.5 \\
\hline \multicolumn{6}{|l|}{ Gelechiidae } \\
\hline Chionodes electella Zeller & M & 0.9 & 0.0 & 0.0 & 0.0 \\
\hline \multicolumn{6}{|l|}{ Batrachedridae } \\
\hline Batrachedra pinicolella Zeller & M & 6.8 & 2.6 & 7.4 & 9.6 \\
\hline \multicolumn{6}{|l|}{ Tortricidae } \\
\hline Archips oporana L. & M & 0.0 & 0.4 & 2.7 & 0.5 \\
\hline Pandemis cinnamomeana Treitschke & M & 0.5 & 0.0 & 0.0 & 0.0 \\
\hline Pandemis cerasana Hübner & M & 0.0 & 0.0 & 0.4 & 0.5 \\
\hline Dichelia histrionana Frölich & M & 5.5 & 4.7 & 1.6 & 4.3 \\
\hline Pseudohermenias abietana $\mathrm{F}$. & M & 0.5 & 0.4 & 0.4 & 1.0 \\
\hline Epinotia nanana Treitschke & M & 0.0 & 0.4 & 1.2 & 0.5 \\
\hline Epinotia pygmaeana Hübner & M & 0.0 & 0.9 & 0.4 & 1.9 \\
\hline Zeiraphera griseana Hübner & M & 0.0 & 0.4 & 0.4 & 0.5 \\
\hline \multicolumn{6}{|l|}{ Lasiocampidae } \\
\hline Dendrolimus pini $\mathrm{L}$. & F & 0.9 & 0.0 & 0.0 & 0.0 \\
\hline Cosmotriche lobulina Denis and Schiffermüller & $\mathrm{F}$ & 0.0 & 0.0 & 0.0 & 0.5 \\
\hline \multicolumn{6}{|l|}{ Sphingidae } \\
\hline Sphinx pinastri $\mathrm{L}$. & $\mathrm{F}$ & 0.5 & 0.0 & 0.4 & 0.0 \\
\hline \multicolumn{6}{|l|}{ Geometridae } \\
\hline Peribatodes secundaria Denis and Schiffermüller & $\mathrm{F}$ & 10.5 & 14.2 & 9.8 & 9.6 \\
\hline Hylaea fasciaria $\mathrm{L}$. & F & 5.9 & 2.1 & 2.3 & 1.9 \\
\hline Pungeleria capreolaria Denis and Schiffermüller & $\mathrm{F}$ & 1.8 & 0.4 & 5.5 & 3.4 \\
\hline Odontopera bidentata Clerck & $\mathrm{F}$ & 0.0 & 0.4 & 1.2 & 0.0 \\
\hline Macaria spp. comprise of: & $\mathrm{F}$ & 5.9 & 3.4 & 4.7 & 4.3 \\
\hline \multicolumn{6}{|l|}{ M. signaria Hübner } \\
\hline \multicolumn{6}{|l|}{ M. liturata Clerck } \\
\hline Thera variata Denis and Schiffermüller & $\mathrm{F}$ & 4.5 & 2.6 & 5.1 & 3.8 \\
\hline Eupithecia tantillaria Boisduval & $\mathrm{F}$ & 45.9 & 57.1 & 48.8 & 50.0 \\
\hline Eupithecia lanceata Hübner & F & 2.7 & 3.9 & 2.3 & 1.9 \\
\hline \multicolumn{6}{|l|}{ Erebidae (Lymantriinae) } \\
\hline Lymantria monacha $\mathrm{L}$. & $\mathrm{F}$ & 0.5 & 0.4 & 0.8 & 1.0 \\
\hline Orgyia antiqua $\mathrm{L}$. & $\mathrm{F}$ & 0.5 & 0.0 & 0.0 & 0.0 \\
\hline \multicolumn{6}{|l|}{ Erebidae (Arctiinae) } \\
\hline Atolmis rubricollis $\mathrm{L}$. & $\mathrm{L}$ & 2.7 & 3.9 & 2.3 & 1.9 \\
\hline Eilema depressa Esper & $\mathrm{L}$ & 0.9 & 0.0 & 0.0 & 1.4 \\
\hline \multicolumn{6}{|l|}{ Noctuidae } \\
\hline Panthea coenobita Esper & $\mathrm{F}$ & 0.5 & 0.0 & 0.4 & 0.0 \\
\hline Orthosia gothica L. & $\mathrm{F}$ & 0.9 & 1.3 & 0.0 & 1.0 \\
\hline
\end{tabular}

fluctuations of those microenvironments. Also, uneven distribution of abundant species (and guilds) at the end of winter resulted in differences between their assemblages recorded in northern and southern crowns (Fig. 3a).

During the growing season, the late instars of $B$. pinicolella showed quite different distribution pattern within spruce crowns compared with that in the late winter. The number of larvae of this moth decreased in southern and increased in northern crowns on both north- and south-facing slopes (Figs. 1c and 4a). This might be due to dispersal of larvae from southern toward northern crowns. In warmer conditions in spring, the late-instar larvae of this species can move across a tree crown more easily than in winter or at the end of winter. On warm and sunny days of the growing season, the sunlight-exposed microhabitats can be overheated and, thus, not suitable for the larvae of $B$. pinicolella. On cool and cloudy days, however, microclimate of such spots may be close to ambient temperatures and acceptable by the larvae of this species (cf., Rehnberg 2006, Pincebourde et al. 2007). Depending on weather, the same microhabitat may provide suitable, less suitable, or even risky environments for larval development. Active larvae are able to respond to weather changes immediately, looking for microhabitats that meet their thermal requirements. Great qualitative variation in microhabitats (variation in microclimate, food quality, etc.) within tree crowns (Orians and Jones 2001, Roslin et al. 2006, Nakamura et al. 2008, Stoepler et al. 2014) can encourage the locomotion of moth larvae (Hagstrum and Subramanyam 2010). Several studies confirmed within-tree changes in distribution of moth larvae during their development, mostly between upper, middle, and lower crown (Anstey et al. 2002, Fry et al. 2009, Eveleigh and Johns 2014).

Heterogeneity of within-tree resource and shifting of acceptable and risky spots within tree crowns (Pincebourde et al. 2007) could also explain nonsignificant effect of crown or slope aspect on the abundance of the two common species of free-living larvae P. secundaria and E. tantillaria and all the larvae within this guild (Fig. 4b). Free-living larvae of many moth species can move actively for a long distance (e.g., Lance and Barbosa 1981, Hansen et al. 1984, 

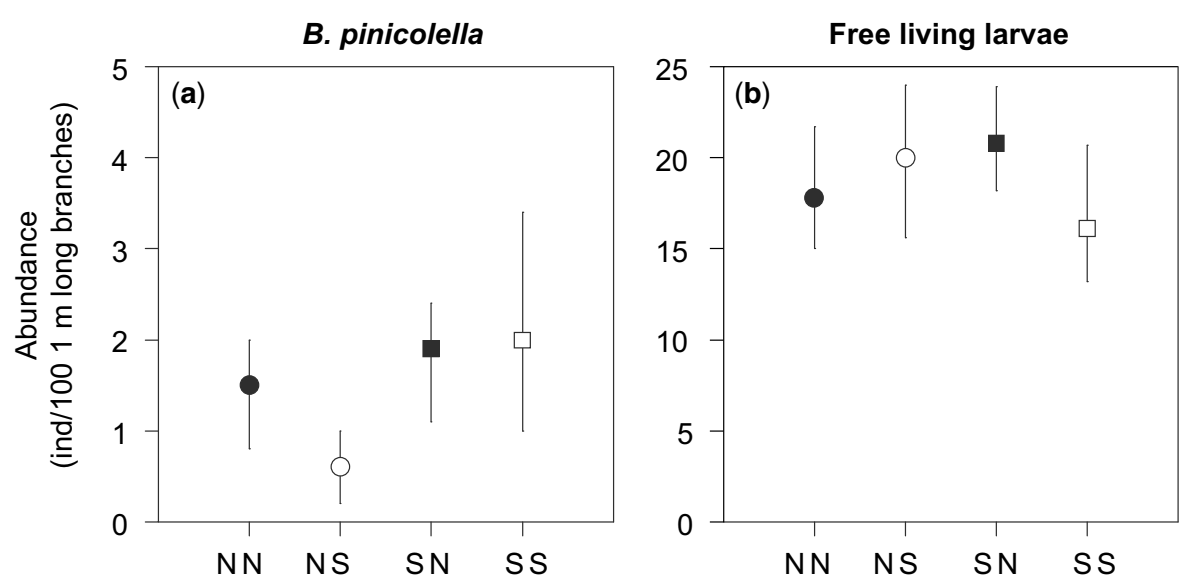

Fig. 4. Mean abundance of moth larvae in northern (solid symbols) and southern crowns of trees (empty symbols) on north-facing (circles) and south-facing slopes (squares) during the growing season. Habitats are denoted using four combinations of slope and crown aspect (e.g., NS-north-facing slope and southern crown). Error bars denote $95 \%$ bootstrap confidence intervals.

Kaitaniemi et al. 2004). Some geometrid larvae are active also in winter (Dvořáćková and Kulfan 2009), seeking suitable places during their whole development. Moreover, laboratory experiments suggest that $P$. secundaria and E. tantillaria do not show a narrow preference for illuminated or shaded parts of branches (Dvořáčková et al. 2010). Free-living larvae prevailed in samples from the growing season; therefore differences between assemblages could not be detected (Fig. 3b).

The risk of mortality due to unfavorable abiotic conditions, inappropriate food, and natural enemies (e.g., pathogens, parasitoids, and predators) may also influence the density of moth larvae in particular microhabitats. Uneven impact of natural enemies on phytophagous insects in the forest canopy in various habitats (Robinson and Holmes 1982; Gunnarsson 1983, 1996; Whelan 2001; Böhm et al. 2011; Barber and Wouk 2012; Leite et al. 2012; Mody et al. 2012; Drozdova et al. 2013; Stoepler and Lill 2013; Eveleigh and Johns 2014) and variations in patterns of larval survival within tree crowns (Gripenberg and Roslin 2005, Connor 2006, Low and Hanley 2012) have been well documented, however, not in the case of moth larvae living on Norway spruce.

Using equal sampling effort, each of the four treatments from the late winter yielded quite different number of individuals (Fig. 2a). Species richness recorded approximated the calculated number of species by the estimators in three treatments (Table 2); in southern crowns on south-facing slopes greater sampling effort should be made. Samples from the growing season provided similar number of individuals and species in all treatments (Fig. 2b). In contrast to winter, more samples are necessary to record expected species richness in particular treatments (Table 2). Unrecorded species are expected to be scarce.

It may be concluded that sampling of moth larvae at the end of winter results in greater differences between the four treatments (northern or southern crowns of Norway spruce trees on north- or south-facing slopes) than that applied during the growing season. Differences in occurrence of free-living larvae between the four treatments were small, indicating similar distribution pattern. The use of emergence boxes and beating spruce branches are complementary, providing valuable insights into the assemblage structure of moth larvae on Norway spruce. To characterize occurrence of moth larvae on this tree species more adequately, we recommend sampling them from different parts of spruce crowns (cf., Stork et al. 2001, Roslin et al. 2006) and different slope aspects during the growing season and in winter. Factors affecting distribution of moth larvae within the crowns of Norway spruce trees on various slope aspects (the role of egg-laying females, efficiency of larval moving, and mortality rate of offspring) need further investigations.

\section{Acknowledgments}

We thank Milada Holecová from the Comenius University (Bratislava, Slovakia) and three anonymous reviewers for valuable comments on the former versions of the manuscript. Peter Tuček and Branislav Kršiak assisted with field studies. The study was supported by the grants VEGA 2/0110/09, $2 / 0035 / 13$ and $2 / 0052 / 15$.

\section{References Cited}

Aarvik, L., and A. Bakke. 1999. The moth (Lepidoptera) fauna of coastal spruce forest at Almdalen Forest Reserve, Namsos, and continental forest in Lierne, Central Norway. Norw. J. Entomol. 46: 9-17.

Alonso, C. 1997. Choosing a place to grow. Importance of within-plant abiotic microenvironment for Yponomeuta mahalebella. Entomol. Exp. Appl. 83: 171-180.

Anstey, L. J., D. T. Quiring, and D. P. Ostaff. 2002. Seasonal changes in intratree distribution of immature balsam fir sawfly (Hymenoptera: Diprionidae). Can. Entomol. 134: 529-538.

Ashton, S., D. Gutierrez, and R. J. Wilson. 2009. Effects of temperature and elevation on habitat use by a rare mountain butterfly: Implications for species responses to climate change. Ecol. Entomol. 34: 437-446.

Auslander, M., E. Nevo, and M. Inbar. 2003. The effects of slope orientation on plant growth, developmental instability and susceptibility to herbivores. J. Arid Environ. 55: 405-416.

Barber, N. A., and J. Wouk. 2012. Winter predation by insectivorous birds and consequences for arthropods and plants in summer. Oecologia 170: 999-1007.

Basset, Y. 1991. The spatial distribution of herbivory, mines and galls within an Australian rain forest tree. Biotropica 23: 271-281.

Basset, Y., N. D. Springate, H. P. Aberlenc, and G. Delvare. 1997. A review of methods for sampling arthropods in tree canopies, pp. 27-52. In N. E. Stork, J. Adis, and R. K. Didham (eds.), Canopy arthropods. Chapman \& Hall, London, United Kingdom.

Battisti, A., M. Stastny, S. Nether̀er, C. Robinet, A. Schopf, A. Roques, and S. Larsson. 2005. Expansion of geographic range in the pine processionary moth caused by increased winter temperatures. Ecol. Appl. 15: 2084-2096.

Bennie, J., B. Huntley, A. Wiltshire, M. O. Hill, and R. Baxter. 2008. Slope, aspect and climate: Spatially explicit and implicit models of topographic microclimate in chalk grassland. Ecol. Model. 216: 47-59. 
Böhm, S. M., K. Wells, and E. K. Kalko. 2011. Top-down control of herbivory by birds and bats in the canopy of temperate broad-leaved oaks (Quercus robur). PLoS ONE 6: e17857.

Bolker, B. M., M. E. Brooks, C. J. Clark, S. W. Geange, J. R. Poulsen, M. H. H. Stevens, and J. S. S. White. 2009. Generalized linear mixed models: A practical guide for ecology and evolution. Trends Ecol. Evol. 24: 127-135.

Bolov, A. P. and S. Yu. Sinev. 1990. Batrachedra pinicolella Dup. (Lepidoptera, Batrachedridae) - A pest of conifers in Kabardino-Balkaria. Entomol. Rev. 69: 16-20.

Bray, J. R., and J. T. Curtis. 1957. An ordination of the upland forest communities of southern Wisconsin. Ecol. Monogr. 27: 325-349.

Canty, A., and B. Ripley. 2015. Boot: Bootstrap R (S-Plus) functions. R package version 1.3-15. https://cran.r-project.org/web/packages/boot/boot.pdf.

Chiu, C. H., Y. T. Wang, B. A. Walther, and A. Chao. 2014. Improved nonparametric lower bound of species richness via a modified Good-Turing frequency formula. Biometrics 70: 671-682.

Cock, M. J. 2013. Batrachedra nuciferae, an inflorescence-feeding moth associated with coconut, Cocos nucifera, and palmiste, Roystonea oleracea, in Trinidad, West Indies. J. Insect Sci. 13: 124. (doi:10.1673/031.013.12401)

Connor, E. F. 2006. Effects of the light environment on oviposition preference and survival of a leaf-mining moth, Cameraria hamadryadella (Lepidoptera: Gracillariidae), on Quercus alba L. Ecol. Entomol. 31: 179-184.

Connor, E. F., and M. P. Taverner. 1997. The evolution and adaptive significance of the leaf-mining habit. Oikos. 79: 6-25.

Crawford, H. S., and D. T. Jennings. 1989. Predation by birds on spruce budworm Choristoneura fumiferana: Functional, numerical, and total responses. Ecology 70: 152-163.

Davidian, M., and D. M. Giltinan. 1995. Nonlinear mixed effects models for repeated measurement data. Chapman and Hall, London, United Kingdom.

Drozdova, M., J. Šipoš, and P. Drozd. 2013. Key factors affecting the predation risk on insects on leaves in temperate floodplain forest. Eur. J. Entomol. 110: 469-476.

Dudt, J. F., and D. J. Shure. 1994. The influence of light and nutrients on foliar phenolics and insect herbivory. Ecology. 75: 86-98.

Dvořáčková, K., and J. Kulfan. 2009. Caterpillars overwintering on spruce roost near their food. Folia Oecologica 36: 75-78.

Dvořáčková, K., J. Kulfan, and P. Zach. 2010. Does the behaviour of spruce caterpillars improve the effect of their crypticity? Pol. J. Ecol. 58: 145-152.

Efron, B., and R. Tibshirani. 1986. Bootstrap methods for standard errors: Confidence intervals and other measures of statistical accuracy. Stat. Sci. 1: 54-77.

Eveleigh, E. S., and R. C. Johns. 2014. Intratree variation in the seasonal distribution and mortality of spruce budworm (Lepidoptera: Tortricidae) from the peak to collapse of an outbreak. Ann. Entomol. Soc. Am. 107: 435-444.

Fournier, D. A., H. J. Skaug, J. Ancheta, J. Ianelli, A. Magnusson, M. N. Maunder, A. Nielsen, and J. Sibert. 2012. AD Model builder: Using automatic differentiation for statistical inference of highly parameterized complex nonlinear models. Optim. Method Softw. 27: 233-249.

Fry, H. R., D. T. Quiring, K. L. Ryall, and P. L. Dixon. 2009. Influence of intra-tree variation in phenology and oviposition site on the distribution and performance of Ennomos subsignaria on mature sycamore maple. Ecol. Entomol. 34: 394-405.

Gower, J. C. 1966. Some distance properties of latent root and vector methods used in multivariate analysis. Biometrika 53: 325-338.

Grant, G. G., B. Zhao, and D. Langevin. 2000. Oviposition response of spruce budworm (Lepidoptera: Tortricidae) to aliphatic carboxylic acids. Environ. Entomol. 29: 164-170.

Grant, G. G., J. Guo, L. MacDonald, and M. D. Coppens. 2007. Oviposition response of spruce budworm (Lepidoptera: Tortricidae) to host terpenes and green-leaf volatiles. Can. Entomol. 139: 564-575.

Gripenberg, S., and T. Roslin. 2005. Host plants as islands: Resource quality and spatial setting as determinants of insect distribution. Ann. Zool. Fennici 42: $335-345$.

Gripenberg, S., E. Morriën, A. Cudmore, J. P. Salminen, and T. Roslin. 2007. Resource selection by female moths in a heterogeneous environment: What is a poor girl to do? J. Anim. Ecol. 76: 854-865.
Grossmueller, D. W., and R. C. Lederhouse. 1985. Oviposition site selection: An aid to rapid growth and development in the tiger swallowtail butterfly, Papilio glaucus. Oecologia 66: 68-73.

Gunnarsson, B. 1983. Winter mortality of spruce-living spiders: Effect of spider interactions and bird predation. Oikos 40: 226-233.

Gunnarsson, B. 1996. Bird predation and vegetation structure affecting spruce-living arthropods in a temperate forest. J. Anim. Ecol. 65: 389-397.

Hagstrum, D. W., and B. Subramanyam. 2010. Immature insects: Ecological roles of mobility. Am. Entomol. 56: 230-241.

Hansen, J. D., J. A. Ludwig, J. C. Owens, and E. W. Huddleston. 1984. Larval movement of the range caterpillar, Hemileuca oliviae (Lepidoptera: Saturniidae). Environ. Entomol. 13: 415-420.

Hayes, A. J., and V. M. Shipp. 1983. Distribution of the green spruce needle miner Epinotia nanana Treitschke (Lepidoptera: Tortricidae) within and between trees at Redesdale, Northumberland. Forestry 56: 195-205.

Heiermann, J., and S. Schütz. 2008. The effect of the tree species ratio of European beech (Fagus sylvatica L.) and Norway spruce (Picea abies (L.) Karst.) on polyphagous and monophagous pest species - Lymantria monacha L. and Calliteara pudibunda L. (Lepidoptera: Lymantriidae) as an example. For. Ecol. Manage. 255: 1161-1166.

Holecová, M., and M. Kulfan. 2011. Weevil fauna (Coleoptera, Curculionoidea) associated with Scots pine growing on blowing sand dunes of the Záhorie region (SW Slovakia). Folia Faunistica Slovaca 16: 9-15.

Hurlbert, S. H. 1971. The nonconcept of species diversity: A critique and alternative parameters. Ecology 52: 577-586.

Kaitaniemi, P., H. Vehviläinen, and K. Ruohomäki. 2004. Movement and disappearance of mountain birch defoliators are influenced by the interactive effects of plant architecture and induced resistance. Ecol. Entomol. 29: 437446.

Karisch, T. 1995. Die Schmetterlinge der Fichtenwälder des Hochschwarzes (Insecta: Lepidoptera). Faunistische Abhandlungen. Staatliches Museum für Tierkunde in Dresden 20: 89-132.

Klepikov, M. A. 2011. Lepidopteran pests in the Upper Volga area (Lepidoptera). Entomol. Rev. 91: 306-311.

Kosibowicz, M., W. Grodzki, and M. Jachym. 2014. Local outbreak of the spruce needle tortricid Epinotia tedella Clerk (Lepidoptera, Tortricidae) in the Sudetes in Poland. Beskydy 7: 29-38.

Kulfan, J. 1994. Zur Saisondynamik der Raupenzönosen (Lepidoptera) an Fichten. Entomol. Probl. 25: 63-72.

Kulfan, J. 1998. Zur Struktur der Zönosen der Raupen an Fichten und Tannen (Lepidoptera). Folia Oecologica 24: 181-187.

Kulfan, J., and J. Patočka. 1997. Über die Fichten-Silbermotten (Lepidoptera, Yponomeutidae, Argyresthiinae) in den Westkarpaten. Anzeiger für Schädlingskunde, Pflanzenschutz, Umweltschutz 70: 92-96.

Kulfan, J., and V. Šušlík. 1995. A simple monitoring method of moth larvae (Lepidoptera) on Norway spruce in the tatra biosphere reserve. Ekológia (Bratislava) 14: 11-18.

Kulfan, J., E. Kula, P. Zach, K. Dvořáčková, J. Patočka, and B. Kršiak. 2010. Caterpillar assemblages on introduced blue spruce: Differences from native Norway spruce. All. For. Jagdzeitung 181: 188-194.

Kulfan, M., M. Holecová, and P. Beracko. 2011. Phyllophagous sawflies (Hymenoptera, Symphyta) in pine stands (Pinus sylvestris) in a sandy lowland, Slovakia. Folia Oecologica 38: 176-182.

Kulfan, M., M. Holecová, and P. Beracko. 2013. Dalechampii oak (Quercus dalechampii Ten.), an important host plant for folivorous lepidoptera larvae. Anim. Biodivers. Conserv. 36: 13-31.

Lance, D., and P. Barbosa. 1981. Host tree influences on the dispersal of late instar gypsy moths, Lymantria dispar. Oikos 38: 1-7.

Latałowa, M., and W. O. Van der Knaap. 2006. Late Quaternary expansion of Norway spruce Picea abies (L.) Karst. in Europe according to pollen data. Quat. Sci. Rev. 25: 2780-2805.

Leite, G.L.D., R.V.S. Veloso, E. R. Martins, J. C. Zanuncio, G. W. Fernandes, C.I.M. Almeida, F. S. Ramalho, and J. E. Serrão. 2012. Population of herbivores insects on different sides of Caryocar brasiliense (Caryocaraceae) trees in the Brazilian Cerrado Region. J. Med. Plants Res. 6: 5557-5565.

Lindstrom, M. J., and D. M. Bates. 1988. Newton-raphson and EM algorithms for linear mixed-effects models for repeated-measures data. J. Am. Stat. Assoc. 83: 1014-1022. 
Liška, J., R. Modlinger, and J. Vaněk. 2008. Motýlí fauna (Insecta, Lepidoptera) horské smrčiny $\mathrm{v}$ západních Krkonoších. [Moth (Insecta, Lepidoptera) in a mountain spruce forest in the western Krkonoše mountain range] Opera Corcontica 45: 115-123.

Loftus, G. R., and M. E. Masson. 1994. Using confidence intervals in withinsubject designs. Psychon. Bull. Rev. 1: 476-490.

Low, C., and D. Hanley. 2012. A perspective on the importance of within-tree variation in mortality risk for a leaf-mining insect. Web Ecol. 12: 27-32.

Maiorana, V. C. 1981. Herbivory in sun and shade. Biol. J. Linn. Soc. 15: 151-156.

Mani, M. S. 1968. Ecology and biogeography of high altitude insects, vol. 4. Springer Science \& Business Media, The Hague, Netherlands.

Marquis, R. J., J. T. Lill, and A. Piccinni. 2002. Effect of plant architecture on colonization and damage by leaftying caterpillars of Quercus alba. Oikos 99: 531-537.

Mazza, C. A., J. Zavala, A. L. Scopel, and C. L. Ballaré. 1999. Perception of solar UVB radiation by phytophagous insects: Behavioral responses and ecosystem implications. Proc. Natl. Acad. Sci. USA 96: 980-985.

McCullagh, P., and J. A. Nelder. 1989. Generalized linear models, 2nd edn. Chapman and Hall, London, United Kingdom.

Michalko, M., J. Berta, and D. Magic. 1986. Geobotanical map of Czechoslovakia. Veda, Bratislava, SK.

Mody, K., C. Spoerndli, and S. Dorn. 2012. How parasitoid sex ratio, size and emergence time are associated with fruit tree cultivar, within-orchard tree position and ants. Biol. Control 60: 305-311.

Moore, L. V., J. H. Myers, and R. Eng. 1988. Western tent caterpillar prefer the sunny side of the tree, but why? Oikos 51:321-326.

Nakamura, M., T. Hina, E. Nabeshima, and T. Hiura. 2008. Do spatial variation in leaf traits and herbivory within a canopy respond to selective cutting and fertilization? Can. J. For. Res. 38: 1603-1610.

Navasero, R. C., and S. B. Ramaswamy. 1993. Influence of plant age, water stress, larval damage, and presence of conspecific eggs on oviposition by Heliothis virescens (F.) on cotton. J. Appl. Entomol. 115: 97-106.

O'Hara, R. B., and D. J. Kotze. 2010. Do not log-transform count data. Methods Ecol. Evol. 1: 118-122.

Oksanen, J., F. G. Blanchet, R. Kindt, P. Legendre, P. R. Minchin, R. B. O’Hara, G. L. Simpson, P. Solymos, M. H. H. Stevens, and H. Wagner. 2015. vegan: Community ecology package. $\mathrm{R}$ package version 2.3-0. https://cran.r-project.org/web/packages/vegan/vegan.pdf.

Orians, C. M., and C. G. Jones. 2001. Plants as resource mosaics: A functional model for predicting patterns of within-plant resource heterogeneity to consumers based on vascular architecture and local environmental variability. Oikos 94: 493-504.

Pastorális, G., H. Kalivoda, and Ľ. Panigaj. 2013. Checklist of Lepidoptera recorded in Slovakia. Folia Faunistica Slovaca 18: 101-232.

Patočka, J., J. Burgan, M. Capek, and M. Stolina. 1960. Die Tannenschmetterlinge der Slowakei mit Berücksichtigung der Fauna Mitteleuropas. Verlag des Slowakischen Akademie der Wissenschaften, Bratislava, SK.

Pettersson, R. B., J. P. Ball, K. E. Renhorn, P. A. Esseen, and K. Sjöberg. 1995. Invertebrate communities in boreal forest canopies as influenced by forestry and lichens with implications for passerine birds. Biol. Conserv. 74: 57-63.

Pincebourde, S., H. Sinoquet, D. Combes, and J. Casas. 2007. Regional climate modulates the canopy mosaic of favourable and risky microclimates for insects. J. Anim. Ecol. 76: 424-438.

Pinheiro, J., D. Bates, S. DebRoy, D. Sarkar, and R Core Team. 2015. nlme: Linear and nonlinear mixed effects models. R package version 3.1-120. https://cran.r-project.org/web/packages/nlme/nlme.pdf.

Potter, D. A. 1992. Abundance and mortality of a specialist leafminer in response to experimental shading and fertilization of American holly. Oecologia 91: 14-22.

Pro Natura (ed.). 1997. Schmetterlinge und ihre Lebensräume. Band 2. Fotorotar AG, Egg, CH.

Queiroz, J. M. 2002. Host plant use among closely related Anaea butterfly species (Lepidoptera, Nymphalidae, Charaxinae). Braz. J. Biol. 62: 657-663.
R Core Team. 2015. R: A language and environment for statistical computing. R Foundation for Statistical Computing, Vienna, AT.

Rehnberg, B. G. 2006. Temperature profiles inside webs of the fall webworm, Hyphantria cunea (Lepidoptera: Arctiidae): Influence of weather, compass orientation, and time of day. J. Therm. Biol. 31: 274-279.

Richardson, B. J., S. Burgin, F. F. Azarbayjani, and S. Lutubula. 1997. Distinguishing the woods from the trees, pp. 497-509. In N. E. Stork, J. Adis, and R. K. Didham (eds.), Canopy arthropods. Chapman and Hall, London, United Kingdom.

Robinson, S. K., and R. T. Holmes. 1982. Foraging behavior of forest birds: The relationships among search tactics, diet, and habitat structure. Ecology 63: 1918-1931.

Roslin, T., S. Gripenberg, J. P. Salminen, M., Karonen, B. R. O’Hara, K. Pihlaja, and P. Pulkkinen. 2006. Seeing the trees for the leaves - oaks as mosaics for a host-specific moth. Oikos 113: 106-120.

Schweizerischer Bund für Naturschutz. 1987. Tagfalter und ihre Lebensräume. Arten-Gefährdung-Schutz. Fotorotar AG, Egg, CH.

Schwenke, W. 1978. Die Forstschädlinge Europas, Band 3, Schmetterlinge. Paul Parey, Berlin, DE.

Skaug, H., D. Fournier, B. Bolker, A. Magnusson, and A. Nielsen. 2015. Generalized Linear mixed models using AD model builder. R package version 0.8.1. http://glmmadmb.r-forge.r-project.org/.

Stoeckli, S., K. Mody, and S. Dorn. 2008. Influence of canopy aspect and height on codling moth (Lepidoptera: Tortricidae) larval infestation in apple, and relationship between infestation and fruit size. J. Econ. Entomol. 101: 81-89.

Stoepler, T. M., and J. T. Lill. 2013. Direct and indirect effects of light environment generate ecological trade-offs in herbivore performance and parasitism. Ecology 94: 2299-2310.

Stoepler, T. M., J. T. Lill, and S. M. Murphy. 2014. Intraplant movement of generalist slug caterpillars (Limacodidae: Lepidoptera): Effects of host plant and light environment. Environ. Entomol. 43: 1561-1573.

Stork, N. E., P. M. Hammond, B. L. Russell, and W. L. Hadwen. 2001. The spatial distribution of beetles within the canopies of oak trees in Richmond Park, UK. Ecol. Entomol. 26: 302-311.

Thompson, J. N., and O. Pellmyr. 1991. Evolution of oviposition behaviour and host preference in Lepidoptera. Annu. Rev. Entomol. 65: 65-89.

Torres, V. L. M., J. Stockel, R. Roehrich, and M.M.C. Rodriguez. 1997. The relation between dispersal and survival of Lobesia botrana larvae and their density in vine inflorescences. Entomol. Exp. Appl. 84: 109-114.

Venables, W. N., and B. D. Ripley. 2002. Modern applied statistics with S. 4. edition. Springer, New York, NY.

Venier, L. A., and S. B. Holmes. 2010. A review of the interaction between forest birds and eastern spruce budworm. Environ. Rev. 18: 191-207.

Watt, A. D., N. E. Stork, and M. D. Hunter. 1997. Forests and insects. Chapman and Hall, London, United Kingdom.

Weber, U. M. 1997. Dendroecological reconstruction and interpretation of larch bud moth (Zeiraphera diniana) outbreaks in two central alpine valleys of Switzerland from 1470-1990. Trees 11: 277-290.

Weiss, S. B., D. D. Murphy, and R. R. White. 1988. Sun, slope, and butterflies: Topographic determinants of habitat quality for Euphydryas editha. Ecology 69: 1486-1496.

Whelan, C. J. 2001. Foliage structure influences foraging of insectivorous forest birds: An experimental study. Ecology 82: 219-231.

Zach, P., J. Patočka, J. Kulfan, A. Krištín, and V. Šušlík. 1995. Forest zonation and faunal assemblages of the Polana Biosphere Reserve UNESCO. Ekologia (Bratislava) 14: 353-365.

Zalucki, M. P., A. R. Clarke, and S. B. Malcolm. 2002. Ecology and behavior of first instar larval Lepidoptera. Annu. Rev. Entomol. 47: 361-393.

Zumr, V. 1984. Prostorové rozmístění kůrovců (Coleoptera, Scolytidae) na smrku ztepilém (Picea excelsa Link) a jejich indiference podle lesních vegetačních stupňu [Spatial distribution of bark beetles (Coleoptera, Scolytidae) in Norway spruce (Picea excelsa Link) and their indifference in relation to forest belts]. Lesnictví 30: 509-523. 